This item was submitted to Loughborough's Research Repository by the author.

Items in Figshare are protected by copyright, with all rights reserved, unless otherwise indicated.

\title{
The 'new' politics of education in Britain's changing times
}

PLEASE CITE THE PUBLISHED VERSION

PUBLISHER

(C) Taylor and Francis

VERSION

AM (Accepted Manuscript)

LICENCE

CC BY-NC-ND 4.0

REPOSITORY RECORD

Demaine, Jack. 2019. "The 'new' Politics of Education in Britain's Changing Times”. figshare. https://hdl.handle.net/2134/2525. 
This item was submitted to Loughborough's Institutional Repository by the author and is made available under the following Creative Commons Licence conditions.

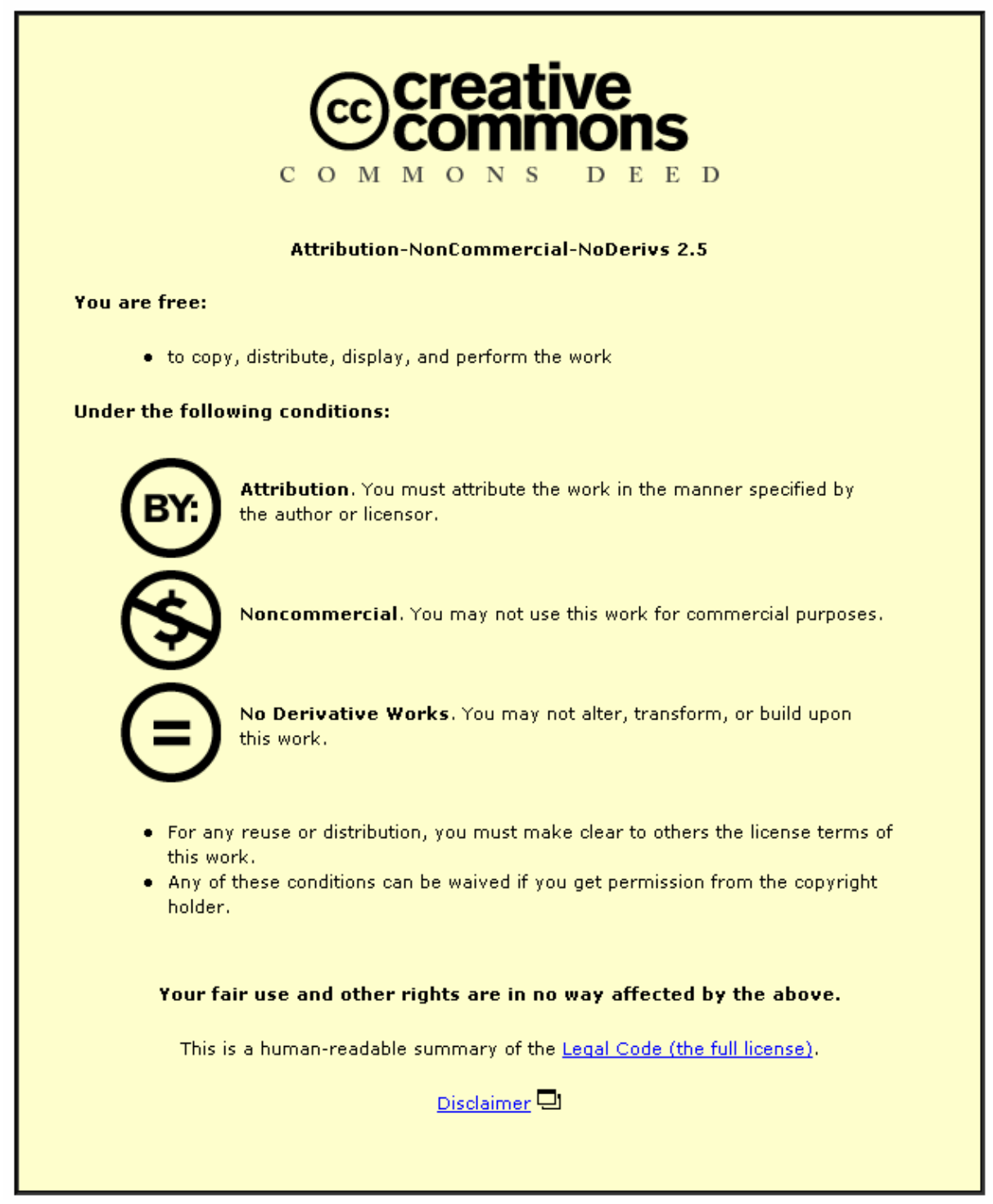

For the full text of this licence, please go to: http://creativecommons.org/licenses/by-nc-nd/2.5/ 
International Studies in Sociology of Education Volume 15 Number 2

The 'new' politics of education in Britain's changing times

\author{
JACK DEMAINE
}

Loughborough University, United Kingdom

\begin{abstract}
The British Labour Party has continued to make progress on education, following two broad policy paths and adopting a pragmatic approach which does not attempt to force these to cross or converge. One path is that of the quasi market inherited from the previous Conservative administration, the other is characterised as 'intervention' to support those for whom the market remains almost entirely irrelevant. Some observers regard this dual approach as 'opportunism' and Labour’s education policy as a 'betrayal' of principle; by which is meant the principle of 'equal opportunity'. But of course, that principle provides equal opportunity to fail as much as to succeed. Rather than leaving education to the market, Labour has focussed on the needs of those most likely to be failed by the principle of 'equal' opportunity in a quasi market.
\end{abstract}


Offering an overview of its achievements so far, and its ambitions for the future, the British Labour Party (2005a) asserts that education is 'central' to its mission to deliver social justice and equality of opportunity (footnote 1). On coming to power in 1997, after 18 years of Conservative government, Labour's 'first task has been to raise achievement and aspirations in every community' so that now parents expect a 'world-class education for their child, regardless of where they live or what they earn'. The Party is said to be committed to extending high quality 'personalised' education to all. Labour sees itself undertaking 'a revolution' in early-years education and care, with a guarantee of a free part-time nursery place for every 3 and 4 year old, more than 500 Sure Start centres and increasing the number of Children's Centres to 3,500 by 2010. Labour reports 'remarkable progress' in education, with 'standards up across the board including the best ever primary school results'. Schools in the 'most deprived areas' are said to have shown the 'greatest improvement in performance'. More breakfast and after school clubs have been organised to 'boost learning and enable all children to participate in a wide range of activities'. There are said to be 'more teachers in schools than at any point in last twenty years'; 28,000 more than in 1997 when Labour came to power, and 105,000 new teaching assistants and support staff. Moreover, Labour plans to rebuild or refurbished every secondary school 'over the next ten to15 years'. Labour claims a 'doubling of funding per pupil since 1997 ' with the aim of reaching at least £5,500 per pupil by 200708. Beyond compulsory schooling, 250,000 young people are said to be benefiting from Labour’s new Education Maintenance Allowances (EMAs) and ‘earn-as-you-learn’ allowances which offer a financial incentive to help combat 'the culture of dropping out' 
at 16. 'Over a quarter of young people' are going on to apprenticeships, and the highest ever number of 18-30 year olds are going on to university. The proportion going into higher education is said to have risen from 'an elite few of around 6 per cent in the 1960s to 44 per cent in 2004’ (cf. Roberts 2004). New proposals will ‘improve access to university for students from all social backgrounds' (all of the quotes cited in this opening paragraph are taken from, The Labour Party, 2005a).

A commitment to continued progress was delineated by Ruth Kelly in her first speech as Secretary of State for Education and Skills at the 2005 North of England Conference. Speaking to teachers, headteachers, other educationists and interested observers Kelly approached the question of the politics of education by saying that,

If like me you are passionate about these things, then you will be pretty frustrated with the often polarised education debate - which does not start from the opportunities for children or the voice of parents. Many on the right believe, with deep pessimism, that the future must be like the past; that standards are only maintained if a majority fail and a minority succeed - when, in the modern age, we can and must be hugely more ambitious and optimistic about our young people and their potential to succeed at school, with the right teaching and support. Some on the left still fall into the trap of excusing educational failure by reference to poverty. In the 21st century, where every young person needs a good education to succeed, both these positions are outdated and profoundly wrong. (Kelly, 2005a) 
In these opening remarks Kelly appears to demonstrate little understanding of either 'left' or 'right' politics of education. Her caricature of 'these positions' would itself appear to be 'profoundly wrong'. Moreover, and of perhaps more concern for sociologists of education, she at first gives the impression of having little knowledge of the last fifty years of research in the field. However, the main thrust of her speech relies to a certain extent on the research findings of sociology of education and related social policy fields. The 'new' politics of education in these 'changing times' owes much to sociology of education whilst at the same time understating the significance both of right and left positions in the recent reconstruction of Labour's politics of education in Britain.

Kelly's assertion that 'Many on the right believe, with deep pessimism, that the future must be like the past; that standards are only maintained if a majority fail and a minority succeed' is evidently wrong. In a nutshell, the right wants to see a further and much more radical shift in the way education is provided such that it would be very different from the past (see for example Tooley, 2000). Indeed, the right wants much of what Kelly goes on to say that she wants to see, asserting that for her it is a 'matter of principle that choice should be expanded where we can - so that parents can increasingly choose between excellent local schools with different strengths and have choice within the curriculum in all schools’ (Kelly, 2005a). Like the right, Kelly is also keen on the notion of 'empowered local headteachers' and for good measure deplores 'badly behaved pupils' who 'damage their own education and those of their classmates' (ibid). Appropriately empowered heads, she says, 'have the right to exclude pupils and use other sanctions for the good of the pupil and the good of the wider school' (ibid.). Choice, parent power, 
headteacher power, discipline and good behaviour of pupils is common ground for new Labour and for the new right.

Kelly's assertion that, 'Some on the left still fall into the trap of excusing educational failure by reference to poverty’ is grotesque caricature of complex differences in arguments on the left. Of course, her caricature is qualified by the word 'some' but no reference is made to any specific person or leftist perspective. I know of no one on the left who excuses failure by reference to poverty. Rather, socio-economic conditions form part of the explanation of differences in educational outcomes (see Demaine, 2003 for further discussion). Such explanations are by no means confined to the left. Sir Keith Joseph, often referred to as the most right wing Secretary of State for Education of the 20th century, made much use of similar explanations and in particular the notion of ‘social deprivation' (Joseph, 1972 ). According to a recent commentator 'Sir Keith Joseph was a very interesting politician, far removed from his stereotype as a harsh Right-winger...(who) developed a research programme to discover the facts behind his concept of the 'cycle of deprivation'. It was a concept that drew attention to the interaction of poor education attainment, poverty, emotional impoverishment, depression and despair’ (Owen, 2000). Joseph’s remedies were not so dissimilar from those offered by Kelly and whilst many 'on the left' (to adopt her phrase) reject simplistic deterministic notions and the discourse of 'cycle of deprivation' they have nevertheless long deployed the notion of 'social reproduction' to explain the relationship between inequality, poverty and educational outcomes (for example see Bourdieu and Passeron, 1977; Mortimore and Whitty, 1997; and for further see Demaine, 2003). 


\section{'diverse' educational opportunity}

For many, but by no means not all on the left (footnote 2), and for some on the right, the way to address social disadvantage, which is now widely acknowledged as the most significant condition leading to differential educational outcomes, is to enhance the educational experience of children before they start school. This, together with earlier commencement of primary schooling, as such, and the improvement of primary and secondary education generally, are the main planks of the new politics of education. Of course, both primary and secondary schooling have become increasingly differentiated as these sectors have responded to 'quasi market' conditions over the last decade or so (Ball, 2003; Demaine, 1990 inter alios). With respect to post-compulsory education, Labour has introduced education maintenance allowances (EMAs) in an attempt to encourage young people from less well off families into further education, and higher education has been expanded so that there are now more university places available than at any time in history. Of course, universities remain highly selective and the social distribution of places strongly reflects social class differences as is evident from comparing Oxford and Cambridge with, say, Derby and Luton universities. As Ken Roberts (2004) rightly argues, 'Elite routes - through the UK’s 'best secondary schools into the 'best' universities then into the best jobs - remain intact'.

Indeed, rather than setting out to attack elite routes, Labour is more concerned with the diversity of provision and with its quality. In order to achieve its aim of overall 
improvement in the quality and diversity of educational provision, Labour is more than willing to embrace the 'independent' school sector and to widen the development of quasi-independent secondary schooling within the state-maintained sector. Tony Blair proposes that 'specialist schools will become near universal, and there will be 200 entirely new academies - free to parents, with no selection by ability - run by independent sponsors in areas where schools have been weak or failing in the past' (Blair, 2004). He goes on to say that he 'will be happy to see these sponsored not just by individual entrepreneurs but also by companies: by churches and other faiths; and by the independent school sector. 200 is what we believe we can achieve. But if we can do more, we will. We will also promote a far stronger vocational pathway leading from school into apprenticeships and further education, so that the overwhelming majority of 16-18 year olds, not just those on a track to university, remain engaged in education or formal training and we make irrelevant the outdated concept of an education leaving age of 16’ (ibid.).

Labour's policy for the youngest children from least well-off families has been based on early provision via Sure Start leading to the phased introduction of children's centres. The Sure Start programme aimed to 'improve the health and well-being of families and children before and from birth, so children are ready to flourish when they go to school' (Department for Education and Employment, 1999). It began to do this in the early 2000s by setting up local Sure Start programmes to improve services for families with children under the age of four, and spreading good practice learned from local programmes to everyone involved in providing services for young children. Sure Start works with 
parents-to-be, parents and children 'to promote the physical, intellectual and social development of babies and young children - particularly those who are disadvantaged so that they can flourish at home and when they get to school, and thereby break the cycle of disadvantage for the current generation of young children' (ibid.). The older discourse on 'deprivation' has been replaced by one on 'disadvantage' and Sure Start is said to be a 'cornerstone' of the Government's drive to tackle child poverty and social exclusion.

But Sure Start was only the first phase of government-funded programme aimed at children and their families in the most disadvantaged neighbourhoods providing 'joined up’ services as envisaged in the government’s Green Paper Every Child Matters (2003). By 2004 about 500 local Sure Start programmes were established, concentrated in neighbourhoods where about 400,000 children live in disadvantaged circumstance; including a third of all under 4s living in poverty. £452 million was invested in Sure Start between 1999 and 2001 and an additional £580 million between 2001 and 2004. There is a proposed budget of about $£ 2$ billion by 2007-8 to expansion the scheme and build the Children's Centres (see Department for Education and Skills, 2003). This programme forms a central plank in Labour's policy of reducing child poverty. From 2003 local authorities were given responsible for planning the centres which will incorporate Sure Start by 2006. Children's Centres will integrate early education with childcare and family support and health services, and enhance links between schools and jobcentres. The government's aim is to provide flexible, seamless and consistent services so that all families will experience a co-ordinated approach to family care that will lead to the 
promotion of the physical, intellectual and emotional development of young children. The Children's Centre will generally be the first contact point for families expecting babies, and 'outreach facilities' will ensure that the centres become 'pro-active' in contacting families with children. Critics claim that Sure Start will be altered in all but name and some observers argue that much it still to be done if its good work is not to be undone in the next phase of reform (Collins and Byrne, 2005; Alakeson, 2005. For further discussion see Melhuish, 2002; Department for Education and Skills, 2003;).

The reform of Sure Start and the development of Children's Centres constitute an important element of Kelly’s appraisal of Labour's achievements so far, as do plans for the future. She argues that,

We have made enormous progress since 1997. For the first time, the Government has recognised the transformative potential of investment in early years education. Our commitment to the expansion of Sure Start children's centres and high quality early learning, will mean that every child starts school at the age of four or five ready to learn. We have had the best ever results in primary schools this year. Steadily improving results at Key Stage 3 and at GCSE. Radical reductions in the numbers of failing schools. More specialist schools with improving standards. The development of a new relationship with schools. Unprecedented stability in school funding. More young people studying for A level and more taking up apprenticeships. Record numbers going to University. And more and more adults 
rescued from the lack of basic skills. All underpinned by record investment (Kelly, 2005a).

Nevertheless, she suggest that 'significant challenges’ remain. For example, 'no one can be content when the gap in entry to higher education between lower and higher social classes remains stubbornly wide. There can be no room for complacency when the type of job you get depends increasingly on your parent's incomes. Or where the lower a school's GCSE results, the more likely it is to have had significant numbers of pupils entitled to free school meals'. Kelly goes on to say that she does not 'underestimate the scale of these challenges. Nor do I pretend to know all the answers' (ibid., emphasis added). We shall come to the Tomlinson Report shortly.

\section{inequality of opportunity in the quasi market}

There may well be no 'answers' in the current and foreseeable future because laudable and radical as Labour's policy is for disadvantaged families, the 'other side’ of Labour's policy continues to enhance the advantages of the already advantaged and their children. Rather than addressing the inequality between schools and the disadvantages of those with 'significant numbers of pupils entitled to free school meals' (a proxy for socioeconomic disadvantage) Labour's policies continue to have the effect of sustaining social differentiation at all levels of education - primary, secondary, tertiary. The 'elite routes', as Roberts calls them, are not new but they have been further entrenched by policies that commodify education; policies inherited from the era of Conservative administration and 
left more or less intact over Labour's two terms in government. Tony Blair's 1997 mantra 'Education, Education, Education', repeated during the 2001 and 2005 election campaigns, echoes the estate agents’ mantra 'Location, Location, Location’ (footnote 3). The family's location in the housing market, its location on household income-scales and its location within what some writers refer to as 'cultural capital' continue to be the most significant factors in securing access to elite routes (Demaine 2003). Education is not, never has been and almost certainly never will be 'level playing field'. Rather, it is an energised field of competition particularly amongst the intermediate and middle classes. As 'state education takes on more of the commodified characteristics of business ... the risks of reproduction become more immediate' (Ball and Vincent, 2001). The 'fearful middle classes', personified in the main by mothers, find themselves working increasingly hard in their attempts to perpetuate their own social class standing in their offspring (ibid. and see Ball, 2003).

Kelly tacitly acknowledges this in her 2005 North of England Conference speech and goes further, saying that

parents want their children's individual needs to be recognised, understood and responded to - 'personalisation' in education jargon. Every parent knows that all children are unique with different talents, different strengths and different weaknesses...we need to meet the needs of every individual child and find different ways of supporting, developing and raising the aspirations of all children (Kelly, 2005a) 
She argues that 'This is what good teachers and good schools have always done - asked themselves the question "how do I help each and every child in my class achieve their potential?” But not all schools have done so. And the policies of successive governments have not always properly supported teachers and schools in that quest' (ibid.). This is confirmed by David Bell (2005) Head of the Office for Standards in Education (Ofsted) and Chief Inspector of Schools. Commenting on Ofsted's most recent annual report which shows that 332 English schools were on 'special measures' by the end of 2004, Bell also points out that one school in ten was 'not improving fast enough'. Bell reports that a thousand schools across the country were failing to make enough progress by the end of the 2003-04 academic year.

\section{intelligent accountability and responding to parents}

In his 2004 North of England Conference speech, Schools Minister David Miliband had made much of the notion of 'personalised learning' (Miliband, 2004). For him 'personalisation’ was not ‘jargon’ but neither did it involve ‘individualised learning'. Rather, he argued that it involves ‘careful attention to children’s individual learning styles, motivations, and needs, rigorous use of pupil target setting linked to high quality assessment and lesson that are well paced and enjoyable. Personalised learning involves pupils who are supported by partnership with others beyond the classroom, high expectation of every child given practical form by high quality teaching based on a sound 
knowledge and understanding of each child's needs' (Miliband, 2004). Fine words with which few would disagree but how is this to be achieved? Miliband argued, somewhat vaguely, and with other questions rather than detailed answers, that 'it can only be developed school by school. It cannot be imposed from above. The question facing us today is simple: what do we need to do to make personalised learning the defining feature of our education system? I think it requires a new relationship between the Department, LEAs and schools, that brings a sharper focus to our work at national level, and strips out clutter and duplication through stronger alignment of all activity, in order to release greater local initiative and energy. The aim is, and I am determined that the result will be, schools with more time to focus on what really matters, more help in identifying their weaknesses, and more tailored and coherent support in putting them right' (ibid.). More fine words but not a detailed policy-recommendation.

By 2005, Miliband’s rhetoric of 2004 became ‘jargon’ for Kelly but nevertheless both see the way forward as being through 'accountability'. For Kelly it is a question of 'responding to parents'; the media have made much of the fact that she is a parent and so "knows what is needed”. For Miliband, parents are important but 'intelligent accountability' is the way forward. Accountability is not something confined to education, it is 'in some ways the foundation of public services today. Without accountability there is no legitimacy; without legitimacy there is no support; without support there are no resources; and without resources there are no services’ (Miliband, 2004). He goes on to suggest that accountability 'should not be a necessary evil. Instead it should be a valuable tool. In the new relationship with schools, we need to move 
beyond defending the need for an accountability framework, and respond to those who want it to work better to promote high performance ... intelligent accountability serves two functions: it helps the system learn from itself; and it shows the public that they are getting value for money' (ibid). All very well but, again, not an education policy as such.

\section{differentiation and contextualised provision}

Argument for accountability is hardly new. The Callaghan government commissioned the Taylor Report (1977) which proposed specific mechanisms for the election of school governors including parents and community representatives (see Demaine, 1981). Of course, there is more to accountability than the formal mechanisms of representation; the experience of school accountability and 'responsiveness' depends on specific conditions in individual schools which vary considerably. An important condition is the 'disposition' of the Chair of governors and even more importantly the disposition headteacher. Ruth Lupton reports on 'The Farcliffe School' and on how the headteacher there sees things. 'This isn't a school; it’s a family, a social services department, and the rest. If we're going to improve on education, these other things have got to be dealt with' (cited in Lupton, 2004). Lupton goes on to report that the evidence of her research suggests that to be effective, school improvement policy needs to contextualized; there is a need for the recognition that, 
some of the practices in schools in disadvantaged areas are necessarily different from those in other areas and that differentiated provision is needed, adapted to the specific needs in each school. This would mean adjusted curriculum, learning resources and pedagogic approaches, to enable effective teaching and learning to take place... teachers need to be equipped with suitable resources for working with low ability pupils, and mechanisms need to be developed to transfer expertise from special needs to mainstream education, in recognition of the fact that some lower sets are effectively special needs groups, requiring teaching techniques with which mainstream teachers are not necessarily equipped (Lupton, 2004)

There is nothing abstract about accountability here, and no 'excuses' for underachievement, just practical policy ideas to address specific contexts including concrete proposals on the effective engagement of parents rather than regarding them a outsiders or 'customers'. Of course, none of this will bring about 'equality' of educational opportunity or ‘equality’ of educational outcome because the more advantaged families who send their children to other schools, the 'fearful middle classes', will be working hard to secure their advantage. Sure Start, the new Children’s Centres, joined-up services, school improvement and the rest will not be sufficient to break the link between poverty, inequality and differential educational outcomes. But if the break with the quest for unachievable 'equality', and the rhetoric that has surrounded it for so many decades, is replaced by the realism of contextualised and accountable education which addresses the real needs of children, that will be an achievement worth striving for. Labour's new politics of education needs to continue to pay close attention to relevant 
research that is informed by a sociological perspective but, as a political party seeking to continue to remain in government, Labour also needs to pay very close attention to its electorate. It is in this context that Kelly's response to the Tomlinson Report must be seen.

\section{Labour and the Tomlinson Report}

The October 2004 report by Mike Tomlinson, the much respected former Head of the Office for Standards in Education and Chief Inspector of Schools, presents a detailed, comprehensive and radical set of proposals for the reform of 14-19 education over a ten year period (Tomlinson, 2004). This is not the place to attempt to review a 116 page document that contains such detailed, well argued recommendations for reform; it would be impossible to do credit to Tomlinson's immense labour. What is of interest, here, is the political context in which the report was published - just a little over six months before the 2005 General Election - and its representation in the British media.

Despite Tomlinson's detail and careful argument for educational reform, media headlines focused on the suggestion that Tomlinson had dropped a 'hot potato' on Labour's lap by recommending the 'abolition of A-levels and the replacement of GCSE'; precisely the aspects of education that the middle classes and aspiring working classes value. A-levels have long been regarded as 'the gold standard', as Mrs Thatcher was often heard say, and although GCSE was initially regarded with suspicion by the middle classes, when 
introduced in the mid 1980s, two decades on they have acquired a similar status. In this context, and with an election imminent, the newly appointed Secretary of State for Education and Skills, Ruth Kelly, presented the new White Paper to Parliament on Wednesday 23 February 2005.

Kelly began her Statement to the House (Kelly, 2005b) by immediately acknowledging Tomlinson before going on to report on Labour's 'progress in raising standards in our schools' and, of course, recommending the new White Paper (14-19 Education and Skills (2005) .

I would like to start by putting on record my thanks to Sir Mike Tomlinson and his working group members for their time and effort. They issued us with a challenge - how to fulfil the needs and aspirations of every single young person. Today I will be setting out how we will meet that challenge. (Kelly, 2005b)

In the highly charged context of an up-coming election, perhaps inevitably, the media and to some extent the teacher unions and professional associations, have paid relatively little attention to Labour's acknowledgement of the work of Tomlinson, and his group, and to the fact that the report has not been consigned to the dustbin of history. The main focus has been on the retention of A-levels and GCSE. Now, although this has been interpreted by the left as a 'lack of political will and a betrayal', from the analytical perspective taken in this paper Labour's policy is quite explicable and entirely consistent 
with what I have called its 'two broad policy paths'. In order to continue to be electable, the British Labour Party perceives the need to appeal (correctly in my view) to the wider electorate; to working class Labour voters and to middle class Labour voters without whose support the Party would itself be consigned to the dustbin of history. Of course, elections are not won or lost on education policy alone but no political party seeking to form a government can afford to ignore any area of social policy.

\section{Conclusions}

The dividing line in education in Britain today is not between those families who subscribe to 'private' schooling and those who make use of 'state' provision; it is between those who can compete for advantage and those who are not in a position so to do. Two stands of policy address these two constituencies. The quasi market allows the better off to compete for advantage by securing places in what they regard as the 'best schools' be they in the private sector or the state sector. A second strand of policy addresses provision for those not in a position to compete. This involves the Sure Start programme and the provision of Children's Centres, the focus on numeracy and literacy in primary schools (most middle class children are already able to read before they arrive at school), school improvement targets for primary and secondary schools together with a range of other 'initiatives'; EMAs to encourage young people from less well off families to take advantage of further education from 16 to 19 , and more accessible universities including those whose entry requirements are much less stringent than for earlier generations when only around $6 \%$ of young people were able to gain access. It is best to 
avoid the temptation of regarding these two stands as together constituting a 'third way'. As I have argued elsewhere "there are no "ways" but only possibilities contingent on a range of circumstances themselves partly the products of earlier conditions' (Demaine, 1999). Labour has made progress along two broad policy paths by adopting a pragmatic approach which does not attempt to force them to cross or converge. Some call such an approach ‘opportunism’ and regard Labour’s education policy as a 'betrayal’ of principle; by which is meant the notion of 'equal opportunity'. But of course, as R.H Tawney (1931) pointed out many decades ago, and others more recently (Coleman, 1969), that principle provides equal opportunity to fail as much as to succeed. Rather than leaving education to the market, Labour has focussed on the needs of those most likely to be failed by the principle of equal opportunity in the market. In so doing it has not closed, and cannot close, the social 'gap' in educational outcomes measured by achievement in public examinations. As Hills and Stewart (2005) report, whilst Labour has made 'genuine progress in reducing disadvantage, especially among families with children’ Britain nevertheless remains a ‘very unequal society’.

There is no reason to imagine that Labour's education policies will make a difference to Britain's unequal society and every reason to think that such policies will continue to sustain inequality of educational outcomes. But Labour's focus on educational opportunities for the disadvantaged should be judged on its own terms and not on its inability to address 'unequal society’ as such. As Basil Bernstein is often quoted as arguing, 'education cannot compensate for society’. But of course he, and others since, have not argued that there is no scope for improvement in either. This paper has argued 
that, like it or not, Labour's education policy is best understood in the context of contemporary social and political conditions.

\section{Notes and Acknowledgements}

1. The first draft of this paper was completed in January 2005 and the final draft a few days after the publication of Britain forward not back, The Labour Party Manifesto (2005b) but before the May 2005 General Election, as such. As one would assume, aspects of the chapter on education in the manifesto closely follow 14-19 Education and Skills (2005) the February White Paper (Command 6476).

2. This is a good point at which to say thanks, and to acknowledge the comments of the anonymous readers of the first draft of this paper. I have benefited from their incisive reading and for their helpful and constructive comments. But there is one aspect on which I must disappoint. In a piece of this length it is not possible to elaborate and debate the many and various positions on either the left or the right. I am very well aware of the inadequacy of such phrases as, "many of the left” and "some on the right” but to engage properly with the wide range of opinion would take a very much longer paper or even a book. I am not at all sure that such effort is really worthwhile since "many" of the “positions” adopted are politically so unrealistic and without sufficient party political support as to make them remote and untenable. Current Labour Party policy is quite a 
different matter, which is why I have chosen to focus on it in this short paper; and only a very narrow aspect of policy, at that.

3. I am grateful to my colleague Dennis Smith for pointing out that Tony Blair's mantra echoes that of the estate agent (realtor for American readers). I take full responsibility for the interpretation that follows.

\section{References}

Alakeson, V. (2005) 2020 vision for early years. London: Social Market Foundation.

Ball, S. J. and Vincent, C. (2001) New Class Relations in Education: the Strategies of the ‘Fearful’ Middle Classes, in J. Demaine (Ed.) Sociology of Education Today. Basingstoke and New York: Palgrave Macmillan.

Ball, S. J. (2003) Class Strategies and the Education Market: The middle classes and social advantage. London: RoutledgeFalmer.

Bell, David (2005) Annual Report of Her Majesty's Chief Inspector of Schools 2003/04. London: The Stationery Office. 
Blair, Tony (2004) Building the opportunity society. Speech at Beveridge Hall, University of London, 11 October

Bourdieu, P. and Passeron, J. C. (1977) Reproduction in Education, Society and Culture. London: Sage.

Coleman, J.S. (1969) Equality of Educational Opportunity. Washington, D.C.:

Government Printing Office. Reprinted in Coleman, J. S. (1969) What is meant by an ‘equal educational opportunity’? Oxford Review of Education, 1:1.

Collins, P. and Byrne, L. (2005) Reinventing Government Again. London: Social Market Foundation.

Demaine, J. (1981) Contemporary Theories in the Sociology of Education. London: Macmillan.

Demaine, J. (1990) The Reform of Secondary Education, in B. Hindess (Ed.) Reactions to the Right. London: Routledge.

Demaine, J. (1992) The Labour Party and Education Policy, British Journal of Educational Studies, 40:3. 
Demaine, J. (1999) Education Policy and Contemporary Politics, in J. Demaine (Ed.)

Education Policy and Contemporary Politics. London: Macmillan.

Demaine, J. (2003) Social Reproduction and Education Policy, International Studies in Sociology of Education, 13:2

Department for Education and Employment (1999) Sure Start: a guide for trailblazers. London: The Stationery Office.

Department for Education and Skills (2003) Sure Start: children's centres - developing integrated services for young children and their families. London: The Stationery Office.

Every Child Matters (2003) a Green Paper presented to Parliament by the Chief Secretary to the Treasury (Command 5860) London: HMSO.

14-19 Education and Skills (2005) A White Paper presented to Parliament by the Secretary of State for Education and Skills (Command 6476) London: HMSO.

Gillborn, D. and Mirza, H. S. (1998) Educational Inequality: Mapping Race, Class and Gender. London: Office for Standards in Education.

Hills, J and Stewart, K (2005) A more equal society? New Labour, poverty, inequality and exclusion. Bristol: The Policy Press. 
Kelly, Ruth (2005a) Speech to the North of England Conference, University of Manchester, 6 January

Kelly, Ruth (2005b) A Statement to Parliament by the Secretary of State for Education and Skills, 23 February

Labour Party, The (2005a) Education, www.labour.org.uk, 1 February

Labour Party, The (2005b) Britain forward not back (The Labour Party Manifesto 2005). London: The Labour Party.

Lupton, R. (2004) Schools in Disadvantaged Areas: Recognising context and raising quality (CASE paper 76) London: Centre for the Analysis of Social Exclusion.

Melhuish, E. et al. (2002) National Evaluation: Early Experiences of Implementing Sure Start. London: Department for Education and Skills.

Miliband, David (2004) Personalised Learning: building a new relationship with schools, Speech to the North of England Conference, Belfast, 8 January

Mortimore, P. and Whitty, G. (1997) Can school improvement overcome the effects of disadvantage? London: Institute of Education. 
Owen, D. (2000) TheFifth Keith Joseph Memorial Lecture, London, 20 January

Roberts, K. (2004) School-to-Work Transitions: why the United Kingdom's educational ladders always fail to connect, International Studies in Sociology of Education, 14:3

Tawney, R.H. (1931) Equality. London: Unwin.

Taylor Report (1977) A New Partnership for Our Schools (Department for Education and Science and Welsh Office). London: HMSO.

Tomlinson, Sir Mike (2004) 14-19 Curriculum and Qualifications Reform: Final Report of the Working Party on 14-19 Reform. London: Department for Education and Skills.

Tooley, J. (2000) Reclaiming Education. Cassell: London and New York. 